\title{
The highest vascular plants on Earth
}

\author{
Cédric Dentant ${ }^{1}[0$
}

Received: 12 January 2018 / Accepted: 12 July 2018

(c) Swiss Botanical Society 2018

\begin{abstract}
Mountaineering, since the beginning of its history, has played an inconspicuous but key role in the collection of species samples at the highest elevations. During two historical expeditions undertaken to reach the summit of Mount Everest in 1935 and 1952, mountaineers collected five species of vascular plants from both the north and south sides of the mountain, at ca. $6400 \mathrm{~m}$ a.s.l. Only one of these specimens was determined immediately following the expedition (Saussurea gnaphalodes), and the remaining four were not identified until quite recently. In 2000, the second specimen from the 1935 expedition was described as a new species for science (Lepidostemon everestianus), endemic to Tibet. In this paper, the remaining three specimens from the 1952 Everest expedition are reviewed and analysed, bringing the number of species sharing the title of "highest known vascular plant" from two to five. I identify one of the 1952 specimens as Arenaria bryophylla, and describe two novel taxa based on analysis of the herbarium records: Saxifraga lychnitis var. everestianus and Androsace khumbuensis. Although elevation records on their own do not inform us about the ecological conditions and physiological capacity of plants at the upper limit of their distribution, this taxonomic investigation contributes to our knowledge of the biogeography of Himalayan flora and opens the way for future field-based investigations of mechanisms limiting plant growth on the roof of the world.
\end{abstract}

Keywords Vascular plants $\cdot$ Lepidostemon everestianus $\cdot$ Androsace khumbuensis · Mountaineering $\cdot$ High elevation · Everest $\cdot$ Himalaya

\section{Introduction}

Mountaineers have a long tradition of contributing to biological knowledge at the upper limits of life. In 1787, during his ascent of Mont Blanc, De Saussure (1796) noted the presence of Silene acaulis subsp. bryoides at an altitude of ca. $3600 \mathrm{~m}$ a.s.l., which is probably the first scientific record of a high-mountain plant. In 1802, Humboldt and Bonpland made famous and complete records of plant species they encountered while climbing Mount Chimborazo (Andes, Ecuador). Despite failing to reach the summit (6263 m a.s.1.), they climbed up to ca. $5880 \mathrm{~m}$ a.s.1. (record for scientists at the time) and

Electronic supplementary material The online version of this article (https://doi.org/10.1007/s00035-018-0208-3) contains supplementary material, which is available to authorized users.

Cédric Dentant

cedric.dentant@ecrins-parcnational.fr

1 Ecrins National Park, Domaine de Charance, 05000 Gap, France noted the upper limit of vascular plants at $4600 \mathrm{~m}$ a.s.l. (von Humboldt and Bonpland 1805). In 1835, during the first ascent of Piz Linard in the eastern Swiss Alps, Heer precisely noted every species he encountered along an elevation gradient. These botanical pioneers established the first links between mountaineering and alpine botany, and paved the way for future scientific monitoring at high elevations (Wipf et al. 2013; Morueta-Holme et al. 2015). During the so-called "Golden Age" of mountaineering in the European Alps (1860-1865), interest in these highest climbing species had increased through years, questioning what renders life possible at such elevations. Between 1861 and 1864, Whymper (1871) recorded several species occurrences during his attempts to reach the summit of the Matterhorn by the south ridge, and noted his fascination with what he called "atoms of life in a world of desolation". Ball (1860), botanist and first president of the Alpine Club of London, published guidelines encouraging mountaineers to participate to Natural History knowledge in recording plants encountered during their tours in upper altitudes. Carret (1880) after examining plants sampled 
during the third ascent of La Meije-one of the last major summits in the Alps to be climbed-declared mountaineering as a new means of extending the study of Natural History to mountain environments, and placed particular emphasis on botany.

For botanists, mountaineering, therefore, became a necessary means of collecting high-elevation biological data for scientific purposes. A striking example of this approach is the first British Reconnaissance Expedition to Mount Everest (1921), during which Wollaston collected what turned out to be at the time the highest vascular plant ever encountered: Arenaria bryophylla, sampled between 6100 and $6200 \mathrm{~m}$ a.s.l. (Miehe 1991). During the same expedition, he also found a primrose new to science: Primula wollastonii. In 1963, members of the American Mount Everest Expedition sampled granular soil near the summit, at $8400 \mathrm{~m}$ (Swan 1992). Researchers found several bacteria within the sample, including a new taxa: Geodermatophilus obscurus subsp. everesti. This discovery prompted scientists to consider the possibility of life on Mars for the first time. The altitude record for visible organisms is $7400 \mathrm{~m}$, on the south face of Makalu, where Aleš Kunaver [cited "T. Kunavar" in Miehe (1991) or "Kunvar" in Miehe (1988) and Körner (2003)], leader of the fourth Yugoslavian Makalu Climbing Expedition, collected two lichens in 1972: Lecidea vorticosa and Lecanora polytropa - the latter species also contained the lichenicole fungus Cercidospora epipolytropa (Miehe 1991). Collectively, these examples illustrate the potential of mountaineering to contribute to our understanding of the upper limits of life in mountain environments.
As the highest mountain on Earth and with rock surfaces present all the way to its summit, Mount Everest $(8848 \mathrm{~m}$ a.s.l.) provides exceptional potential for establishing elevation records for the occurrence of organisms. Two historical Himalayan expeditions were especially significant for the collection of botanical data, in addition to their climbing achievements: the 1935 British expedition, led by Eric E Shipton, and the 1952 Swiss expedition, led by Edouard Wyss-Dunant. The first expedition took place in Tibet, and accessed the base of Mount Everest by way of the East Rongbuk Glacier. Shipton and his colleagues were able to collect two vascular plant specimens at ca. $6400 \mathrm{~m}$ a.s.l., before being forced to turn around below $7100 \mathrm{~m}$ a.s.l. due to a snow storm. The Swiss expedition was the second European expedition to Nepal, accessing Mount Everest from the south along the Khumbu Glacier. During the attempt, scientific members of the expedition collected three vascular plant specimens at ca. $6350 \mathrm{~m}$ a.s.l. (Fig. 1). The party reached the remarkable altitude of $8600 \mathrm{~m}$ a.s.l., and paved the way for the successful British expedition the following year, when Tenzing Norgay and Edmund Hillary reached the summit.

Although the members of the 1935 and 1952 expeditions were unable to identify the species they encountered, they collected samples which they brought back to scientific institutions in Europe. One of the samples collected in 1935, at $6400 \mathrm{~m}$ a.s.l., was later identified as Saussurea gnaphalodes (Royle ex DC.) Sch.Bip.; it is often cited as the highest vascular plant on Earth (Miehe 1991; Bajracharya 1996; Körner 2003). The other sample from 1935 was described as a new species, Lepidostemon everestianus Al-Shehbaz,
Fig. 1 Satellite images of the Mount Everest region with locations of both expeditions samples. Image: (C2018 DigitalGlobe, CNES/Airbus. Map data: (C2018 Google

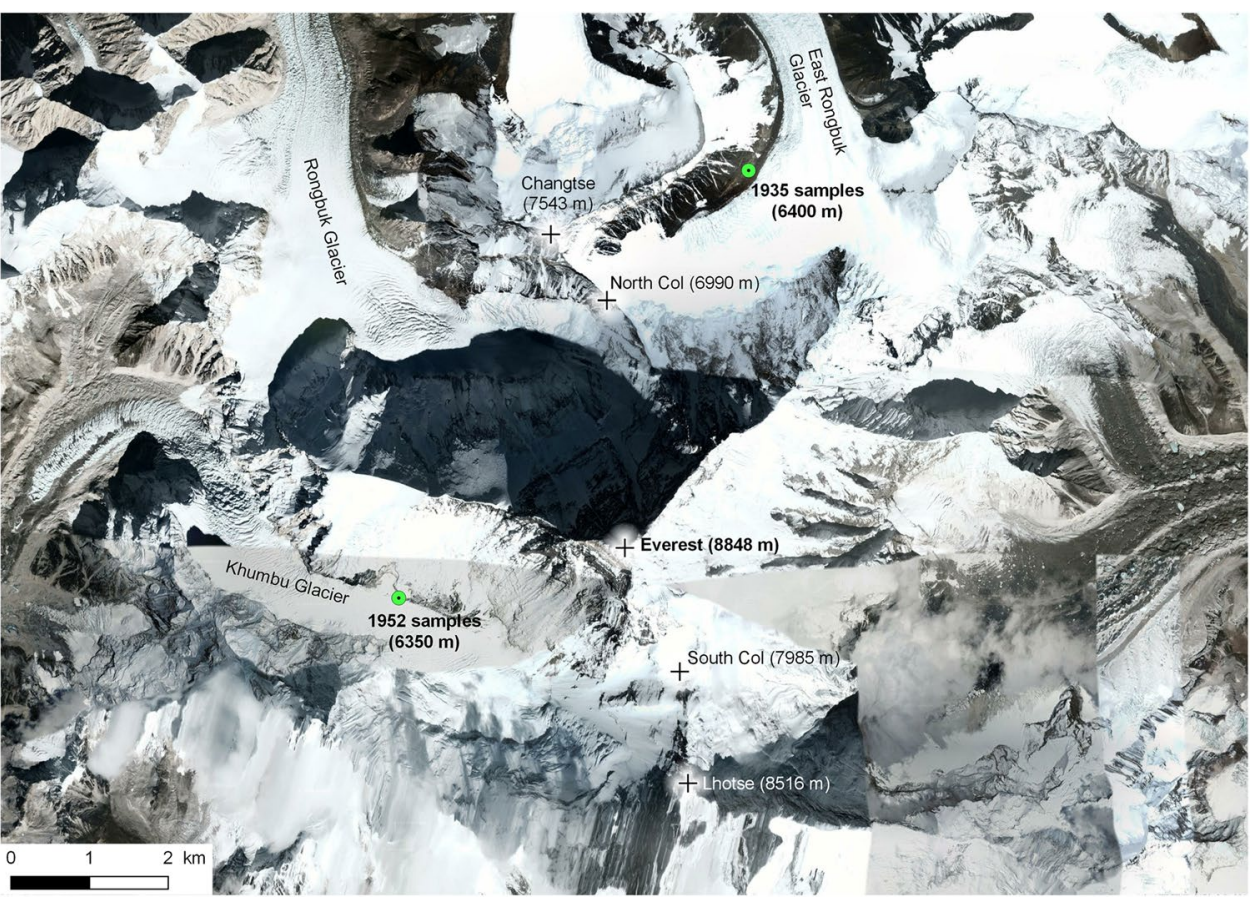


in the recent past (Al-Shehbaz 2000). In contrast, the samples from 1952 were never studied nor identified. To my knowledge, mountaineers on Mount Everest have made no further records of vascular plant life at equivalent or higher elevations since the 1935 and 1952 expeditions.

Herbarium records, such as the samples collected during the 1935 and 1952 Everest expeditions, are an under-utilized source of information about plant occurrences in extreme and remote mountain locations. Even years or decades after initial collection, specimens can (1) provide insight into the upper limits of plant distribution and (2) provide the basis for the description of novel taxa. The aim of this paper is to formally describe these highest climbing plants ever collected, and in so doing contribute to our knowledge of the upper limits of vascular plant life.

\section{Sampling sites}

The British and Swiss expeditions collected a total of five species around $6400 \mathrm{~m}$ a.s.l. Saussurea gnaphalodes (Royle ex DC.) Sch.Bip. is a fairly widespread plant throughout Nepal, Tibet, Pamir and the Hindu Kush, growing usually between 5000 and $6000 \mathrm{~m}$. These characteristics explain why this species was the only one of the five identified soon after the expedition. The original specimen was collected by Shipton in 1935 in the "big scree" bordering the north side of the East Rongbuk Glacier, at Camp III, close to the base of the North Col. Shipton (1936) did not mention any botanical sample in his expedition report, but the label of the herbarium specimen, conserved in the British Museum Herbarium (BM), is explicit and unambiguous.

However, Shipton did not only sample one species at $6400 \mathrm{~m}$ a.s.l., but two. The second one, totally unknown in 1935, was archived in the BM without any name until 2000. Working on the Flora of China project (efloras.org 2008), the worldwide specialist of the Brassicaceae family, Ihsan Al-Shehbaz, came across the sample and described it as a new species: Lepidostemon everestianus (Al-Shehbaz 2000; Fig. 2). Despite the striking elevation, no connection was then made at the time with the other sample collected by Shipton, Saussurea gnaphalodes, which belonged to a family outside the scope of his study. The discovery of Lepidostemon everestianus, a Tibetan endemic, made the genus Lepidostemon no longer monotypic. The specimen collected by Shipton remains the only one ever encountered for this species.

In 1952, on the south (Nepalese) side of Everest, the botanist of the scientific Swiss expedition, Albert Zimmermann, sampled three species on a section of moraine and cliff bordering the north side of the Khumbu Glacier (Zimmermann 1952). The recorded altitudes were $6335 \mathrm{~m}$ a.s.l. for the first species, and $6350 \mathrm{~m}$ a.s.l. for the two others, respectively.

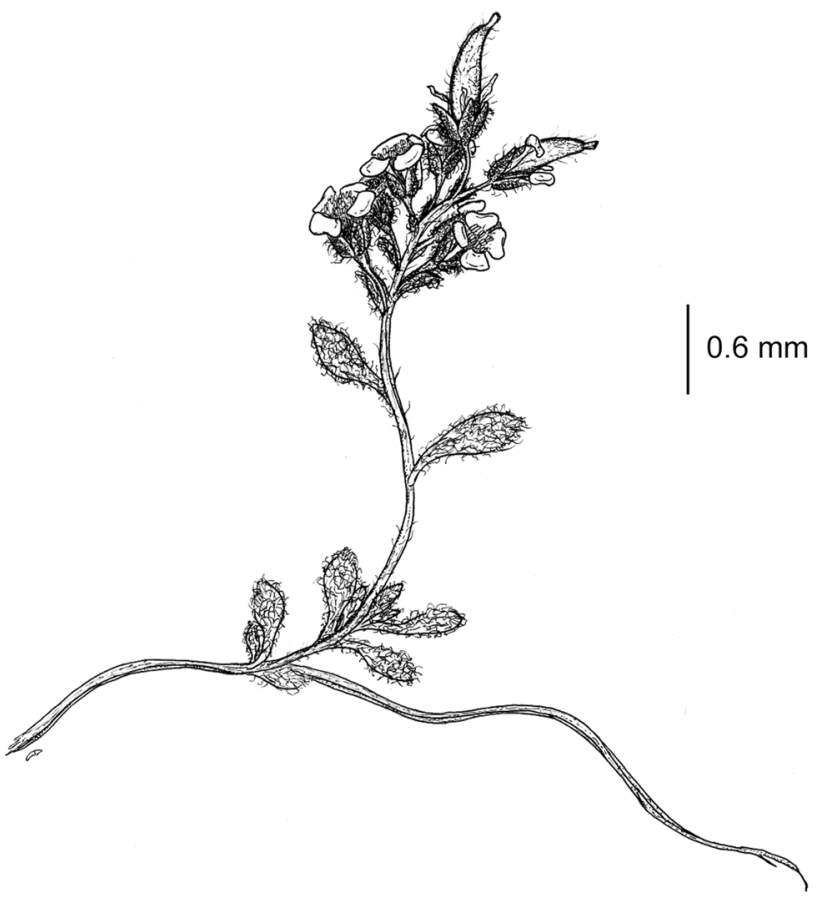

Fig. 2 Illustration of Lepidostemon everestianus based on the herbarium specimen (BM[000587908]) and Al-Shehbaz' description. Drawing: C. Dentant

Zimmermann described the location in which he found the specimens as "between Camp IV and Camp V". However, Camp IV was settled at $6450 \mathrm{~m}$ a.s.l. and Camp V at $6900 \mathrm{~m}$ a.s.l. (Roch 1952)! Zimmermann maintained this location in his report of the expedition, however, as well as on the herbarium labels. The Zimmermann's cited location is an obvious discrepancy: Camp IV was in the middle of the Western Cwm (upper part of the Khumbu Glacier) and Camp V in the slope below the South Col. There is neither rock nor moraine between them. The correct location is between Camp III and Camp IV. Considering this discrepancy and the precision of the tools that were available to assess altitudes in 1935 and 1952 , these three altitude values $(6400,6335$ and $6350 \mathrm{~m})$ can be considered as equivalent.

\section{Taxonomic analysis}

Here, I present an account of the five samples collected from the Mount Everest in 1935 and 1952. The specimens collected in 1935 have already been correctly identified or described elsewhere and are included for comprehensiveness. The three samples from 1952 were studied in May and June 2017 in G (Conservatoire et Jardin botaniques de la Ville de Genève), where they have been stored since collection, using standard methods of herbarium taxonomy. In addition, I relied on the Himalayan herbarium collection at 
G, digitized specimens at BM, E (Flora of Nepal project), $\mathrm{A}$ and MO (Flora of China project), floristic literature and reports based on data collected during the Swiss expedition (Zimmermann 1952; Weibel 1956; Baehni 1958). Zimmermann's unpublished field notebook was also consulted. Herein, he proposed names for the collected specimens: "Arenaria!", "Androsace microphylla!" and "Sedum or Saxifraga". In the expedition report (Zimmermann 1952), he corrected his first hesitation, stating that the third specimen appeared to be without a doubt a tiny Saxifraga.

1. Saussurea gnaphalodes (Royle ex DC.) Sch.Bip.-Tibet (China), East Rongbuk Glacier, big scree, 21,000 ft. (ca. $6400 \mathrm{~m}$ )—07/26/1935—coll.: Eric E Shipton; determin.: s.n. BM[000803807]! (herbarium specimen in Online Resource 1).

A complete description of the taxon can be found in Shi and von Raab-Straube (2008).

2. Lepidostemon everestianus Al-Shehbaz-Tibet (China), East Rongbuk Glacier, big scree, 21,000 ft. (ca. $6400 \mathrm{~m}$ )-07/26/1935-coll.: Eric E Shipton; determin.: Ihsan A Al-Shehbaz (1999). HOLOTYPE: BM[000587908]! (herbarium specimen in Online Resource 2).

A complete description of the taxon can be found in Al-Shehbaz (2000).

3. Arenaria bryophylla Fernald-Nepal, Mount Everest, Khumbu Glacier, moraine, $6335 \mathrm{~m}$, between Camp IV and Camp V-05/25/1952—coll.: Albert Zimmermann (accompanied by E Hofstetter and Aila sherpa); determin.: Cedric Dentant (2017). G[G00429530]! (herbarium specimen in Online Resource 3).

A complete description of the taxon can be found in Zhengyi and Wagner (2008).

This taxon was considered for years as the highest occurring plant in the world (Polunin and Stainton 1997), before Miehe (1991) corrected it with Shipton's sample of Saussurea gnaphalodes. This plant forms dense cushions, with woody caudex. Leaves are linear, crowded and reflexed, forming columns. Leaf margins are involute and membranous. Above $5000 \mathrm{~m}$ a.s.l., two other species of Arenaria may be encountered: A. edgeworthiana and A. pulvinata. With no flower on the sample, the single reliable feature to distinguish $A$. bryophylla is the leaf margin: glabrous or sparsely ciliate for this species; hairy or distinctly ciliate for others.
4. Saxifraga lychnitis Hook.f. \& Thomson var. everestianus Dentant, var. nov. (Fig. 3; herbarium specimen in Online Resource 4)-HOLOTYPE designed here: Nepal, Mount Everest, crevices on south-facing cliffs, 6350 m, between Camp IV and Camp V_-05/25/1952_ coll.: Albert Zimmermann (accompanied by E Hofstetter and Aïla sherpa); determin.: Cedric Dentant (2017). G[G0042528]!

Herbs perennial. Roots mainly primary, with scarce secondary ones. Axillary stems (or stolons?), 1-3 per rosette, short, thick and sparsely leafy. Leaves $2-3.5 \mathrm{~mm}$ long, elliptical, forming lax rosettes, $2.5-4 \mathrm{~mm}$ in diameter. Both leaf surfaces flat, glabrous, eglandular or brownish glandular. Margins uneven, mostly with scarce brownish glandular hair, sometimes only with irregular eglandular teeth. Apex fleshy, sometimes mucronate. Stem leaves longer than rosette's ones, with a conspicuous central rib (absent for rosette leaves). Flowers and fruits unknown.

In Nepal, Saxifraga contains 87 species, including 21 endemics. S. lychnitis belongs to section Ciliatae (because of its entire leaves without chalk glands), which contains 65 species in Nepal (Akiyama et al. 2012). It also includes Saxifraga zimmermannii, which was described in 1958 from Zimmermann's samples collected at other, lower localities during the 1952 expedition (Baehni 1958).

Saxifraga lychnitis can be distinguished from closely related species $S$. stella-aurea, S. llonakhensis, S. harae, and $S$. viscidula, due to its elliptical, mostly brown-glandular leaves, that have no well-defined petiole nor a crisped villous margin, and that are not placed in rows. Var. everestianus differs from var. lychnitis and var. oresbia in the following characters: the presence of short, leafy axillary stems, and smaller leaves and rosettes.

Although variation in leaf size alone would not argue for a varietal status, the combination of its leaves, growth form with axillary stems (which could be interpreted as stolons) and extreme elevation demonstrates that this collection represents a separate taxon. Indeed, the axillary stems, which are buried in the soil and absent from the other two varieties, may represent an adaptation to the plant's extreme habitat. They anchor the plant in the unstable substrate and may protect the base of the stem from freezing (Dvorský et al. 2016).

The species is named after Mount Everest, the only mountain where the variety is known to occur.

5. Androsace khumbuensis Dentant, sp. nov. (Fig. 4; herbarium specimen in Online Resource 5)—HOLOTYPE designed here: Nepal, Mount Everest, crevices in southfacing cliffs, $6350 \mathrm{~m}$, between Camp IV and Camp V-05/25/1952 — coll.: Albert Zimmermann (accompanied by E Hofstetter and Aila sherpa); determin.: Cedric Dentant (2017). G[G00429529]! 
Fig. 3 Saxifraga lychnitis var. everestianus. a Leaves (lf) forming rosette, with several stems (ste) and a short and thick axillary stem (a ste); b individual with loose rosette; $\mathbf{c}$ leaf with glandular hair (gh) on the margin and brown glands (bg) on surfaces; example of glabrous leaf, with short whitish teeth $(\mathrm{t})$. Drawings: C. Dentant
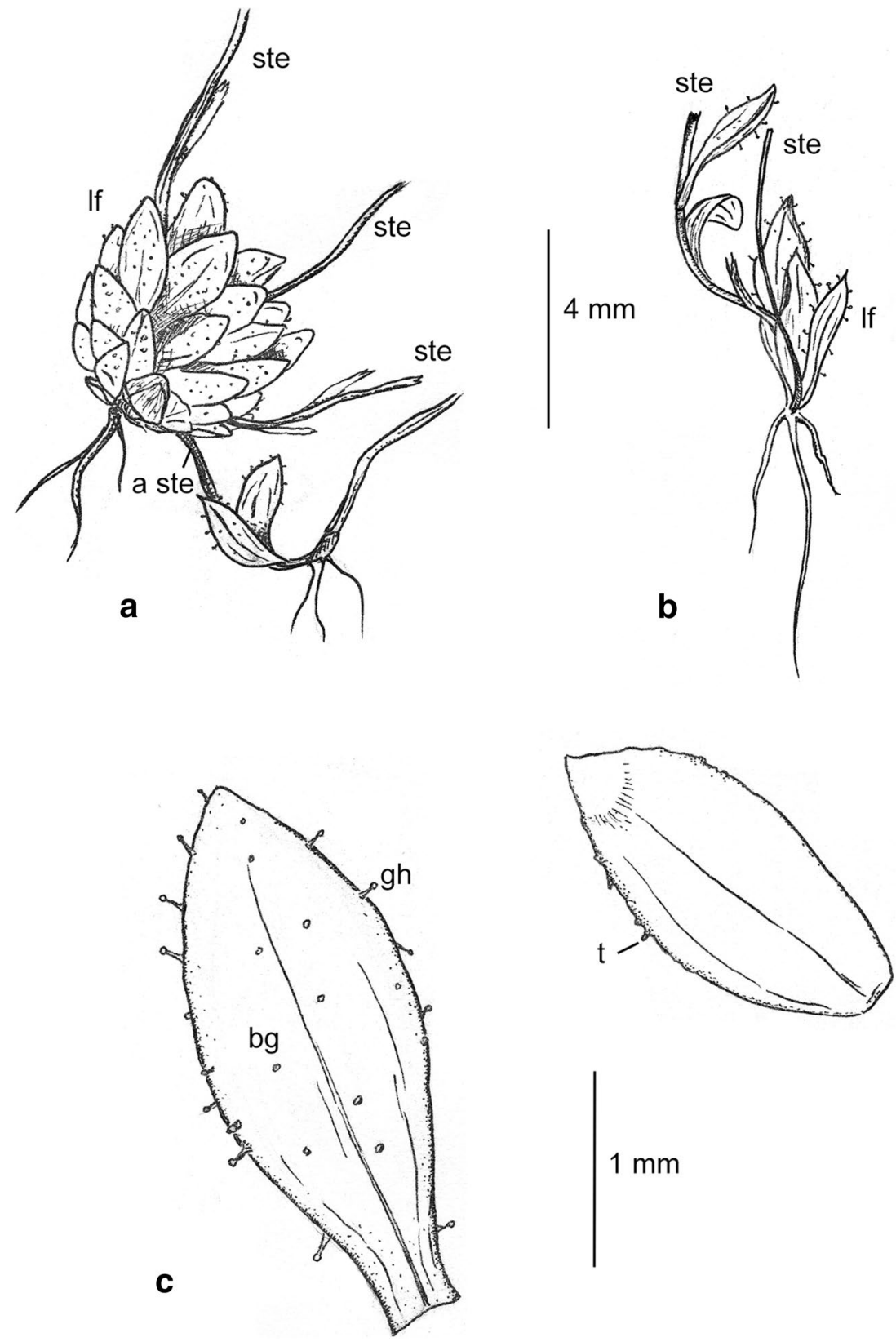

Herbs perennial, forming a more or less dense cushion. Roots mainly primary, with scarce secondary ones. Leaves gathered in numerous rosettes less than $3 \mathrm{~mm}$ in diameter; leaves 1-2.5 mm long, rather homomorphic despite external ones much more curved than inner ones. Abaxial and adaxial leaf surfaces glabrous; margins with scarce and irregular whitish teeth, 0.1-0.4 mm long, more numerous on apex of external leaves. Inner leaves with cartilaginous margins and a conspicuous central rib. Corolla white.

In Nepal, Androsace contains 21 referenced taxa, including 4 infra-taxa (Shrestha and Press 2008). Miehe (1987) cited seven Androsace species from the Everest region of Nepal. The specimen has been compared with all of them with respect to morphology (based on herbarium specimens) and ecological conditions, as well as to all 73 Androsace species from China (Hu and Kelso 2008) and A. mucronifolia, the only species known from Pakistan. Although the specimen is rather poorly preserved, it is clearly distinct from all described species. The specimen lacks reproductive features except for a single corolla; peduncles, sepals, stamens, ovary, fruits and seeds are unknown. Nevertheless, the delineation of A. khumbuensis from closely related species is clear due to its tiny, glabrous, homomorphic, white-teethed leaves. Specifically, in contrast to A. khumbuensis, (1) A. globifera has pointed leaves with a hairy apex (long white hair); (2) A. muscoides has flat leaves, fairly pointed, with a hairy apex (long white 
Fig. 4 Androsace khumbuensis. a Rosette; b external leaf with whitish teeth $(\mathrm{t}) ; \mathbf{c}$ internal leaf, also with whitish teeth (t). Drawings: C. Dentant
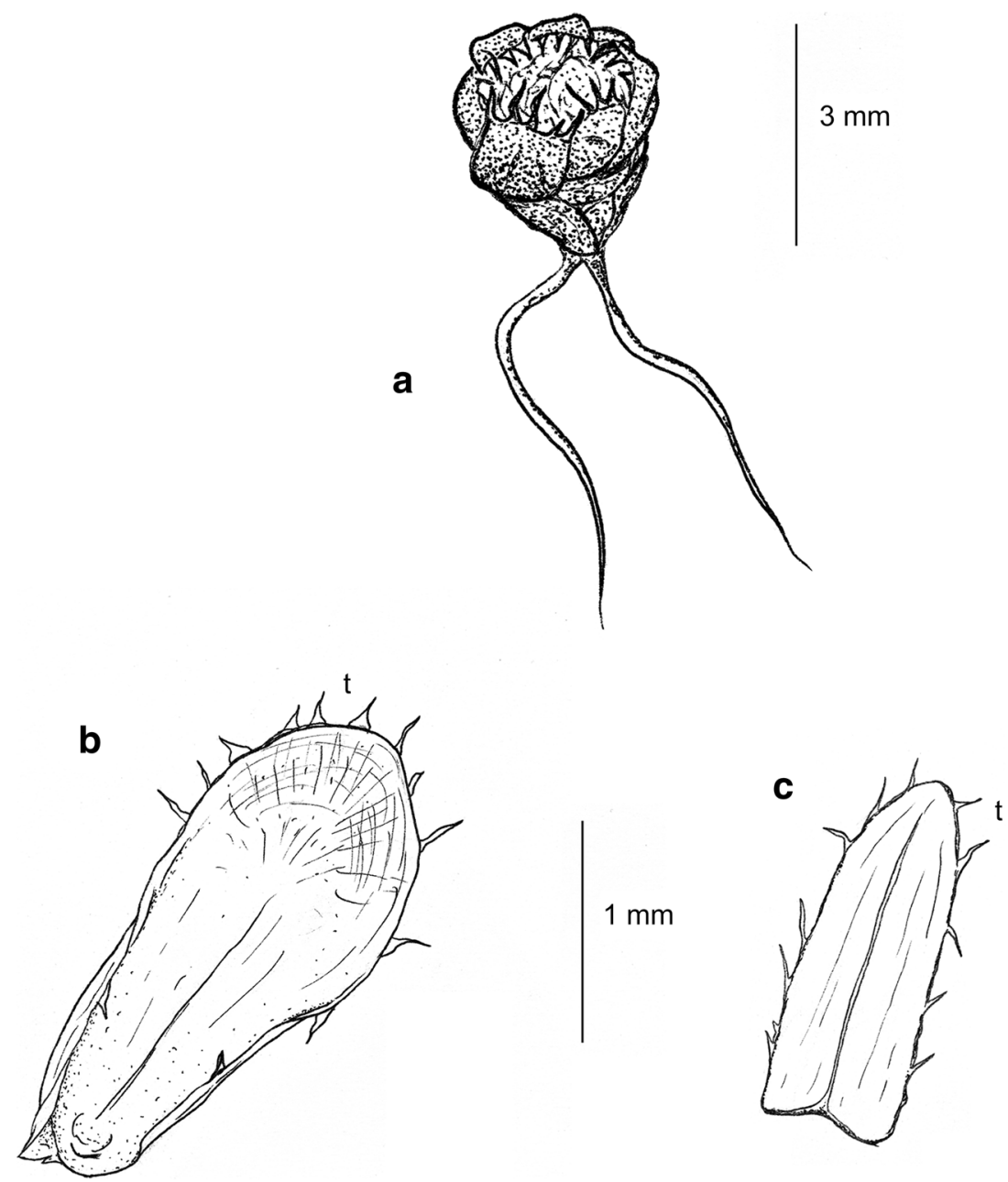

hair); (3) A. delavayi has hairy abaxial surface of leaves; apex hold thin, long $(0.6-0.9 \mathrm{~mm})$ and dense translucent trichomes; leaf length 2-4 mm; (4) A. tapete has hairy leaves, gathered in columns; (5) A. lehmanii has dimorphic leaves, with pink dried corolla (white when fresh); (6) A. mucronifolia (=A. microphylla) is much bigger in all its features, including stolons that are much longer and thicker, and it has leaf margins that are densely setose-ciliate. [This species is cited by Zimmermann (1952) with a question mark; no specimens from Nepal have been encountered.] More specimens would be required to enable a better understanding of this remarkable taxon.

The species is named after the Khumbu Glacier, where the species is described from. It is dedicated to all of the members of the 1952 Swiss expedition for their remarkable blend of mountaineering and science.

\section{Discussion}

High-elevation vascular plants

The five highest vascular species of the world belong to five different families: Asteraceae, Brassicaceae, Caryophyllaceae, Saxifragaceae and Primulaceae. $40 \%$ of the encountered taxa are new for science. In other recent studies carried out in the Himalayan region (Dvorský et al. 2015; Angel et al. 2016), botanists found a similar proportion of new species, recording a total of eight different species belonging to three families at $6150 \mathrm{~m}$ a.s.1.: Brassicaceae (Draba alshehbazii, Draba altaica, Ladakiella klimesii); Asteraceae (Saussurea glacialis, Saussurea 
gnaphalodes, Saussurea inversa, Waldheimia tridactylites) and Poaceae (Poa attenuata). Three out of these eight species were also new discoveries for science and only described very recently, after 2002 (Klimeš and German 2009; German and Al-Shehbaz 2010; von Raab-Straube 2011). Even if records of altitude tell little about life conditions, it is striking to see how little is known about this specific diversity. Two other records known from literature can be mentioned to complete this list of vascular plant occurrences above $6100 \mathrm{~m}$ a.s.l. (Table 1): Desideria himalayensis (=Ermania himalayensis; Brassicaceae) at $6300 \mathrm{~m}$ a.s.l. on Kamet, and Stellaria decumbens (Caryophyllaceae), observed by Swan at $6130 \mathrm{~m}$ a.s.l. on Makalu (Miehe 1991). It is notable that among these 14 different species encountered above $6100 \mathrm{~m}$ a.s.l., most were found to grow in multiple-species patches: Saussurea gnaphalodes and Lepidostemon everestianus (6400 m a.s.1.);
Androsace khumbuensis and Saxifraga lychnitis var. everestianus (6350 m a.s.1.); Draba alshehbazii, Draba altaica, Ladakiella klimesii, Saussurea gnaphalodes, Waldheimia tridactylites and Poa attenuata (6150 m a.s.1.). These results seem to point out favourable sites for colonization of vascular plants in highest elevations rather than accidental occurrences (Angel et al. 2016). Both Everest sites are worth to be investigated anew to (1) check and to compare the species occurrences; (2) gather biological information on encountered species and (3) investigate the local environmental conditions.

\section{Habitat conditions of highest plant occurrences}

Information on the habitats where plant species were collected in 1935 and 1952 is limited to succinct habitat descriptions. Despite the lack of quantitative data on

Table 1 Complete list of vascular plants ever recorded to date (above $6100 \mathrm{~m}$ a.s.l.)

\begin{tabular}{|c|c|c|c|c|c|}
\hline Species $^{\mathrm{a}}$ & Family $^{\mathrm{b}}$ & $\begin{array}{l}\text { Highest } \\
\text { recorded eleva- } \\
\text { tion }(\mathrm{m})\end{array}$ & Mountain & Reference & $\begin{array}{l}\text { Year of first } \\
\text { description }^{\mathrm{c}}\end{array}$ \\
\hline $\begin{array}{l}\text { Androsace khumbuensis } \\
\text { Dentant }\end{array}$ & Primulaceae & 6350 & $\begin{array}{l}\text { Mount Everest (Nepal, East- } \\
\text { ern Himalayas) }\end{array}$ & this study & 2018 \\
\hline Arenaria bryophylla Fernald & Caryophyllaceae & 6335 & $\begin{array}{l}\text { Mount Everest (Nepal, East- } \\
\text { ern Himalayas) }\end{array}$ & this study & 1919 \\
\hline $\begin{array}{l}\text { Desideria himalayensis } \\
\text { (Cambess.) Al-Shehbaz }\end{array}$ & Brassicaceae & 6300 & $\begin{array}{l}\text { Kamet (Garhwal, Western } \\
\text { Himalayas) }\end{array}$ & Miehe (1991) & 1844 \\
\hline $\begin{array}{l}\text { Draba alshehbazii Klimeš \& } \\
\text { D.A.German }\end{array}$ & Brassicaceae & 6150 & $\begin{array}{l}\text { Mount Shukule II (Ladakh, } \\
\text { Western Himalayas) }\end{array}$ & Angel et al. (2016) & 2008 \\
\hline $\begin{array}{l}\text { Draba altaica (C.A.Mey.) } \\
\text { Bunge }\end{array}$ & Brassicaceae & 6150 & $\begin{array}{l}\text { Shukule Peaks (Ladakh, } \\
\text { Western Himalayas) }\end{array}$ & $\begin{array}{l}\text { Dvorský et al. (2015), Angel } \\
\text { et al. (2016) }\end{array}$ & 1841 \\
\hline $\begin{array}{l}\text { Ladakiella klimesii (Al- } \\
\text { Shehbaz) D.A. German \& } \\
\text { Al-Shehbaz }\end{array}$ & Brassicaceae & 6150 & $\begin{array}{l}\text { Shukule Peaks (Ladakh, } \\
\text { Western Himalayas) }\end{array}$ & $\begin{array}{l}\text { Dvorský et al. (2015), Angel } \\
\text { et al. (2016) }\end{array}$ & 2002 \\
\hline $\begin{array}{l}\text { Lepidostemon everestianus } \\
\text { Al-Shehbaz }\end{array}$ & Brassicaceae & 6400 & $\begin{array}{l}\text { Mount Everest (Nepal, East- } \\
\text { ern Himalayas) }\end{array}$ & Al-Shehbaz (2000) & 2000 \\
\hline Poa attenuata Trin. & Poaceae & 6150 & $\begin{array}{l}\text { Mount Shukule II (Ladakh, } \\
\text { Western Himalayas) }\end{array}$ & Angel et al. (2016) & 1835 \\
\hline Saussurea glacialis Herder & Asteraceae & 6150 & $\begin{array}{l}\text { Shukule Peaks (Ladakh, } \\
\text { Western Himalayas) }\end{array}$ & Dvorský et al. (2015) & 1867 \\
\hline $\begin{array}{l}\text { Saussurea gnaphalodes } \\
\text { (Royle ex Royle) Sch.Bip. }\end{array}$ & Asteraceae & 6400 & $\begin{array}{l}\text { Mount Everest (Nepal, East- } \\
\text { ern Himalayas) }\end{array}$ & Miehe (1991) & 1846 \\
\hline $\begin{array}{l}\text { Saussurea inversa Raab- } \\
\text { Straube }\end{array}$ & Asteraceae & 6150 & $\begin{array}{l}\text { Shukule Peaks (Ladakh, } \\
\text { Western Himalayas) }\end{array}$ & Dvorský et al. (2015) & 2011 \\
\hline $\begin{array}{l}\text { Saxifraga lychnitis var. ever- } \\
\text { estianus Dentant }\end{array}$ & Saxifragaceae & 6350 & $\begin{array}{l}\text { Mount Everest (Nepal, East- } \\
\text { ern Himalayas) }\end{array}$ & this study & 2018 \\
\hline Stellaria decumbens Edgew. & Caryophyllaceae & 6130 & $\begin{array}{l}\text { Makalu (Nepal, Eastern } \\
\text { Himalayas) }\end{array}$ & Miehe (1991) & 1846 \\
\hline $\begin{array}{l}\text { Waldheimia tridactylites Kar. } \\
\text { \& Kir. }\end{array}$ & Asteraceae & 6150 & $\begin{array}{l}\text { Shukule Peaks (Ladakh, } \\
\text { Western Himalayas) }\end{array}$ & $\begin{array}{l}\text { Dvorský et al. (2015), Angel } \\
\text { et al. (2016) }\end{array}$ & 1842 \\
\hline
\end{tabular}

${ }^{\text {a }}$ Species names based on The Plant List (theplantlist.org)

${ }^{\mathrm{b}}$ Family names based on APG IV (2016)

${ }^{\mathrm{c}}$ Basionym publication 
ecological conditions in these contexts, previous findings from the literature enable discussion of the environmental constraints operating at $6400 \mathrm{~m}$ a.s.l. on Mount Everest. On the one hand, Saxifraga lychnitis var. everestianus and Androsace khumbuensis were found in rock crevices, which are, according to Miehe (1987), a more suitable substrate for vascular plants at upper elevations on Mount Everest. Indeed, Miehe considers that the most decisive limiting factor for plant colonization at the highest elevations is the daily movement of the substrate by freezing and thawing action during the growing season. Consequently, rock crevices capable of accumulating sun warmth may favour plant colonization, as observed for the highest climbing plant cited in the European Alps: Saxifraga oppositifolia, at $4504 \mathrm{~m}$ a.s.l. (Körner 2011). On the other hand, Saussurea gnaphalodes, Lepidostemon everestianus and Arenaria bryophylla were encountered on scree and moraine, that is to say unstable substrates. According to Dvorský et al. (2016), however, the root-zone temperature is the most important driver for plant colonization and growth, making exposure and micro-topography crucial. This factor is less dependent on soil properties. In both cases, at the highest elevations on Earth, seasonal effects are not to be underestimated: unusual freezing or snowfall can counteract plant colonization. Succession of favourable conditions during the growing season is, therefore, required to the establishment as well as the survival of vascular plants (Dolezal et al. 2016).

\section{Distribution and phylogeny of the highest vascular plants}

The five uppermost taxa found on Mount Everest belong to clades known for being very speciose in cushion plants (Aubert et al. 2014), a life form perfectly suited to arctico-alpine environments and representing an evolutionary convergence among angiosperms (Boucher et al. 2016). These clades display a similar pattern of distribution in Eurasian mountain ranges: they account for $54 \%$ of the nival flora in the Everest region (based on data from Miehe 1987); $49 \%$ in the Hindu Kush; $46 \%$ in Caucasus (Breckle et al. 2017); and more than 52\% in the European Alps (Aeschimann et al. 2011). The striking similarity in the altitudinal distribution of these clades through Eurasia can be illustrated with the late Miocene radiation of the Androsace genus roughly 15 million years ago (Boucher et al. 2012; Roquet et al. 2013). At this time and in this clade, the cushion life form, including many new species, appeared independently in two rising mountain ranges: the European Alps and the Himalaya. This convergent evolutionary history is reflected in taxonomic outcomes such as ongoing discovery of novel taxa in different Eurasian mountains: "Androsace innominata" (provisional name) in the western Alps [see Jordan (2015) and Dentant (2017)],
Androsace komovensis in the Balkans (Schönswetter and Schneeweiss 2009) and now Androsace khumbuensis on Mount Everest. These highest climbing species appear thus to be more than records of plant life. Taxonomic novelties highlight how little we know about plant diversity and evolution in highest elevations.

\section{Conclusion}

Vascular plant species have been documented close to the uppermost elevations of most of the world's great mountain ranges: the elevation record in Africa is $5760 \mathrm{~m}$ a.s.l., on Mount Kilimanjaro (5895 m a.s.l.; Grabherr et al. 1995); in the Andes, the highest vascular plants have been observed at $5800 \mathrm{~m}$ a.s.l. in the tropical part of the range (Halloy 1991). The Everest specimens collected in the 1935 and 1952 expeditions are to date the highest climbing vascular plants observed on Earth. Nevertheless, recent descriptions of new taxa encountered above $6100 \mathrm{~m}$ highlight the need for further investigation on high-elevation growing species. Scarcity of vegetation is certainly not the only factor explaining the little amount of data from upper elevations: sampling is extremely difficult due to the hard access and the harsh environment of high mountains, and to the little investment of modern mountaineers compared to pioneers of the discipline [with exceptions, see Körner (2011) and Marx et al. (2017)]. Without question, it seems timely to encourage a renewed approach to mountaineering, one which integrates awareness of scientific issues and a culture of data collection. Climate change and its consequences on biodiversity could be an interesting point of convergence between mountaineers and scientists. Ongoing effects of recent climate change on alpine plant species are well studied in the European Alps: widespread thermophilization and upward migration of plant species (Gottfried et al. 2012), densification of alpine communities (Carlson et al. 2017), colonization processes and increases in species richness on mountain summits (Kammer et al. 2007; Steinbauer et al. 2018) and predicted habitat loss due to warming (Engler et al. 2011). While similar processes are likely underway in the Himalaya, the general increase in temperature pushing species upwards appears to be potentially and deeply offset by seasonal and occasional adverse conditions, such as repeated snowfalls or freezing events during growing season (Dolezal et al. 2016). Renewal of biological scientific expeditions to Mount Everest, following the example of the recent Czech expeditions in Eastern Ladakh [see Dvorský et al. (2015) and Angel et al. (2016)], would likely allow us to improve our knowledge on diversity and ecological limits of the uppermost taxa, and consequently to improve our understanding of plants' ability to colonize and survive at the upper limits of life. 
Acknowledgements I would like to acknowledge the herbarium curators who provided a decisive assistance for this study: Fred Stauffer and Laurent Gauthier (Conservatory and Botanical Garden of Geneva, G); Ranee Prakash (Natural History Museum of London, BM). I would also thank Fabien Anthelme and Hannah Marx for their advice for improving the manuscript. And finally a special thanks to Sonja Wipf for her indefatigable support and to Brad Carlson for his invaluable contribution in refining the manuscript.

Author contributions C. Dentant analysed herbarium records at the Conservatory and Botanical Garden of Geneva and the British Museum, carried out research on historical expeditions to Mount Everest and wrote the paper.

\section{Compliance with ethical standards}

Conflict of interest The author declares that he has no conflict of interest.

\section{References}

Aeschimann D, Rasolofo N, Theurillat JP (2011) Analyse de la flore des Alpes. 1: historique et biodiversité. Candollea 66:27-55

Akiyama S, Gomall RJ, Adhikari B et al (2012) Saxifragaceae. In: Flora of Nepal (floraofnepal.org). Royal Botanical Garden Edinburg. http://www.floraofnepal.org. Accessed 2017

APG IV (2016) [Angiosperm Phylogeny Group] An update of the Angiosperm Phylogeny Group classification for the orders and families of flowering plants: APG IV. Bot J Linn Soc 181:1-20. https://doi.org/10.1046/j.1095-8339.2003.t01-1-00158.x

Al-Shehbaz IA (2000) Lepidostemon (Brassicaceae) is no longer monotypic. Novon 10:329-333

Angel R, Conrad R, Dvorsky M et al (2016) The root-associated microbial community of the world's highest growing vascular plants. Microb Ecol 72:394-406. https://doi.org/10.1007/s0024 8-016-0779-8

Aubert S, Boucher F, Lavergne S et al (2014) 1914-2014: a revised worldwide catalogue of cushion plants 100 years after Hauri and Schröter. Alp Bot 124:59-70. https://doi.org/10.1007/s0003 5-014-0127-x

Baehni C (1958) Résultats des expéditions scientifiques genevoises au Népal en 1952 et 1954 (partie botanique).13. Juglandaceae, Santalaceae, Thymelaeaceae et Saxifragaceae. Candollea 16:215-227

Bajracharya DM (1996) Phyto-geography of Nepal Himalaya. Tribhuvan Univ J 19:57-76

Ball J (1860) Suggestions for Alpine Travellers. In: Ball J (ed) Peaks, passes and glaciers, 5th edn. Longman, Green, Longman \& Roberts, London

Boucher FC, Thuiller W, Roquet C et al (2012) Reconstructing the origins of high-alpine niches and cushion life form in the genus Androsace s.l. (Primulaceae). Evolution 66:1255-1268. https:// doi.org/10.1111/j.1558-5646.2011.01483.x

Boucher FC, Lavergne S, Basile M et al (2016) Evolution and biogeography of the cushion life form in angiosperms. Perspect Plant Ecol Evol Syst 20:22-31. https://doi.org/10.1016/j.ppees.2016.03.002

Breckle SW, Fayvusch G, Murtazaliev R, Nakhutsrishvili G (2017) Floristic analysis of the subnival-nival vegetation of Hindu Kush and Caucasus. Bielef Ökologische Beitr 21:7-31

Carlson BZ, Corona MC, Dentant C et al (2017) Observed long-term greening of alpine vegetation-a case study in the French Alps. Environ Res Lett 12:114006. https://doi.org/10.1088/1748-9326/ aa84bd
Carret M (1880) Note sur quelques plantes trouvées au pic de la Meije. Ann Soc Bot Lyon 7:171-176

De Saussure H-B (1779-1796). Voyage dans les Alpes. Samuel Fauche (tome I), Geneva; Barde, Manget \& Compagnie (tome II), Geneva; Louis Fauche-Borel (tomes III and IV), Geneva

Dentant C (2017) Flora verticalis. Editions Le Naturographe, Gap

Dolezal J, Dvorsky M, Kopecky M et al (2016) Vegetation dynamics at the upper elevational limit of vascular plants in Himalaya. Sci Rep 6:1-13. https://doi.org/10.1038/srep24881

Dvorský M, Altman J, Kopecký M et al (2015) Vascular plants at extreme elevations in eastern Ladakh, northwest Himalayas. Plant Ecol Divers 8:571-584. https://doi.org/10.1080/17550 874.2015.1018980

Dvorský M, Chlumská Z, Altman J et al (2016) Gardening in the zone of death: an experimental assessment of the absolute elevation limit of vascular plants. Sci Rep 6:1-10. https://doi.org/10.1038/ srep24440

efloras.org (2008) Flora of China. Missouri Botanical Garden. MO \& Harvard University Herbaria, St Louis. Cambridge, MA. http:// www.efloras.org. Accessed 2017

Engler R, Randin CF, Thuiller W et al (2011) 21st century climate change threatens mountain flora unequally across Europe. Glob Chang Biol 17:2330-2341. https://doi.org/10.111 1/j.1365-2486.2010.02393.x

German DA, Al-Shehbaz IA (2010) Nomenclatural novelties in miscellaneous Asian Brassicaceae (Cruciferae). Nord J Bot 28:646-651. https://doi.org/10.1111/j.1756-1051.2010.00983.x

Gottfried M, Pauli H, Futschik A et al (2012) Continent-wide response of mountain vegetation to climate change. Nat Clim Chang 2:111115. https://doi.org/10.1038/nclimate1329

Grabherr G, Gottfried M, Gruber A, Pauli H (1995) Patterns and current changes in alpine plant diversity. In: Chapin FS, Körner Ch (eds) Arctic and alpine biodiversity: patterns, causes and ecosystem consequences. Ecological studies, vol 113. Springer, Berlin, Heidelberg, New York, pp 167-181

Halloy S (1991) Islands of life at $6000 \mathrm{~m}$ altitude - the environment of the highest autotrophic communities on Earth (Socompa Volcano, Andes). Arct Alp Res 23:247-262. https://doi.org/10.2307/15516 02

Hu Q, Kelso S (2008) Primulaceae. In: Flora of China (efloras.org). Missouri Botanical Garden. MO \& Harvard University Herbaria, St Louis. Cambridge, MA. http://www.efloras.org. Accessed 2017

Jordan D (2015) Atlas de la flore rare ou menacée de Haute-Savoie. Naturalia Publications, Turriers

Kammer PM, Schöb C, Choler P (2007) Increasing species richness on mountain summits: Upward migration due to anthropogenic climate change or re-colonisation? J Veg Sci 18:301-306. https:// doi.org/10.1111/j.1654-1103.2007.tb02541.x

Klimeš L, German D (2009) Draba alshehbazii (Brassicaceae), a new species from extreme altitudes of eastern Ladakh (Jammu and Kashmir, India). Bot J Linn Soc 158:749-754. https://doi.org/10 .1111/j.1095-8339.2008.00933.x

Körner C (2003) Alpine plant life, 2nd edn. Springer, Berlin

Körner C (2011) Coldest places on earth with angiosperm plant life. Alp Bot 121:11-22. https://doi.org/10.1007/s00035-011-0089-1

Marx HE, Dentant C, Renaud J et al (2017) Riders in the sky (islands): using a mega-phylogenetic approach to understand plant species distribution and coexistence at the altitudinal limits of angiosperm plant life. J Biogeogr 44:2618-2630. https://doi.org/10.1111/ jbi.13073

Miehe G (1987) An annotated list of vascular plants collected in the valleys south of Mt Everest. Bull Brit Mus Nat Hist 16:225-268

Miehe G (1988) Vegetation patterns on Mount Everest as influenced by monsoon and föhn. Vegetatio 79:21-32. https://doi.org/10.1007/ BF00044845 
Miehe G (1991) Der Himalaya, eine multizonale Gebirgsregion. In: Walter H, Breckle SW (eds) Ökologie der Erde, vol 4. Fischer, Stuttgart, pp 181-230

Morueta-Holme N, Engemann K, Sandoval-Acuña P et al (2015) Strong upslope shifts in Chimborazo's vegetation over two centuries since Humboldt. Proc Natl Acad Sci 112:12741-12745. https://doi.org/10.1073/pnas.1509938112

Polunin O, Stainton A (1997) Flowers of Himalaya. Oxford University Press, Oxford

Roch A (1952) Everest 1952. Jeheber, Geneva

Roquet C, Boucher FC, Thuiller W, Lavergne S (2013) Replicated radiations of the alpine genus Androsace (Primulaceae) driven by range expansion and convergent key innovations. J Biogeogr 40:1874-1886. https://doi.org/10.1111/jbi.12135

Schönswetter P, Schneeweiss GM (2009) Androsace komovensis sp. nov., a long mistaken local endemic from the southern Balkan Peninsula with biogeographic links to the Eastern Alps. Taxon 58:544-549

Shi Z, von Raab-Straube E (2008) Saussurea. In: Flora of China (efloras.org). Missouri Botanical Garden. MO \& Harvard University Herbaria, St Louis. Cambridge, MA. http://www.efloras.org. Accessed 2017

Shipton EE (1936) The Mount Everest reconnaissance, 1935. Himal J 8

Shrestha KK, Press R (2008) Annotated Checklist of the Flowering Plants of Nepal. In: efloras.org. Missouri Botanical Garden. MO \& Harvard University Herbaria, St Louis. Cambridge, MA. http:// www.efloras.org. Accessed 2017
Steinbauer MJ, Grytnes J-A, Jurasinski G et al (2018) Accelerated increase in plant species richness on mountain summits is linked to warming. Nature. https://doi.org/10.1038/s41586-018-0005-6

Swan LW (1992) The Aeolian Biome. Ecosystems of the earth's extremes. Bioscience 42:262-270

von Raab-Straube E (2011) The genus Saussurea (Compositae, Cardueae) in China: taxonomic and nomenclatural notes. Willdenowia 41:83-95. https://doi.org/10.3372/wi.41.41109

von Humboldt A, Bonpland A (1805) Essai sur la géographie des plantes. Levrault, Shoell et compagnie, Paris

Weibel R (1956) Résultats des expéditions scientifiques genevoises au Népal en 1952 et 1954 (partie botanique).4. Primulaceae. Candollea 15:157-165

Whymper E (1871) Scrambles amongst the Alps in the years 1860 1869. John Murray, London

Wipf S, Stöckli V, Herz K, Rixen C (2013) The oldest monitoring site of the Alps revisited: accelerated increase in plant species richness on Piz Linard summit since 1835. Plant Ecol Divers 6:447-455. https://doi.org/10.1080/17550874.2013.764943

Zhengyi W, Wagner WL (2008) Arenaria. In: Flora of China (efloras.org). Missouri Botanical Garden. MO \& Harvard University Herbaria, St Louis. Cambridge, MA. http://www.efloras.org. Accessed 2017

Zimmermann A (1952) Botanique. In: Lobsiger-Dellenbach M, Lombard A, Zimmermann A (eds) Himalaya du Népal. Expédition scientifique genevoise. Jeheber, Geneva 